\title{
A via-crúcis de Jonas no Sertão da Paraíba: interseccionalidade, diferença e o Brasil atual ${ }^{*}$
}

Martinho Tota**

\section{Resumo}

Fruto de uma pesquisa sobre identidades, relações e políticas LGBT no Sertão da Paraíba, o presente artigo, partindo da história de vida de Jonas, um dos interlocutores do autor, consiste, num primeiro momento, em apresentar informações a respeito do Grupo Fórum LGBT Catolé (uma organização não governamental) e das vidas de pessoas gays, lésbicas, travestis e transexuais em uma localidade do Brasil profundo. Num segundo momento, explorando as vicissitudes e o sofrimento do protagonista do texto, lanço mão das noções de interseccionalidade e diferença no intuito de problematizar não apenas a história e a trajetória de um sujeito específico, mas o cenário da geografia político-moral que caracteriza o atual momento da vida brasileira.

Palavras-chave: Movimento LGBT, Sexualidade, Gênero, Interseccionalidade, Diferença.

\footnotetext{
* Recebido em 09 de outubro de 2019, aceito em 10 de julho de 2020.

** Professor de Antropologia no Departamento de Ciências Sociais e no Programa Associado de Pós-Graduação em Antropologia (PPGA/UFC-UNILAB), da Universidade Federal do Ceará (UFC), Fortaleza, CE, Brasil. martinho.tota@gmail.com / https://orcid.org/0000-0001-5068-6627
} 
Jonas's Suffering in the Backlands: Intersectionality, Difference and Brazil Today

\begin{abstract}
This article examines LGBT identities, relations, and policies in the sertão (arid backlands) of Paraíba, Brazil. It considers the life story of Jonas, one of the author's interlocutors, and presents information about the LGBT Group Forum Catole (a non-governmental organization) and the lives of gay, lesbian, transvestite and transgender people in an isolated region of Brazil. It then explores the vicissitudes and suffering of the protagonist of the text, using the notions of intersectionality and difference to analyze not only the history and trajectory of a specific subject but the scenario of political-moral geography that characterizes Brazilian life today.
\end{abstract}

Keywords: LGBT Movement, Sexuality, Gender, Intersectionality, Difference. 
Em cada cartaz de cada esquina o que se estampa é a morte; ou, pior, a tirania; a brutalidade; a tortura; a derrocada da civilização;o fim da liberdade

(Virginia Woolf, Os anos)

\section{Introdução}

No primeiro semestre de 2014, colocando em prática um projeto intitulado "Outros sertões: políticas, relações e identidades LGBT $^{1}$ no Sertão da Paraíba", iniciei uma investigação cujo escopo consistia em apreender questões relacionadas às sexualidades, ao erotismo, às identidades $e$ relações de gênero no Sertão do estado da Paraíba. A ideia era esgaravatar essa temática (ou esse complexo temático) em um contexto social até então pouco explorado por pesquisadoras(es) no Brasil $^{2}$. É certo que hoje, no âmbito das Ciências Sociais, já contamos com um considerável volume de teses de doutorado, dissertações de mestrado, livros e artigos acadêmicos produzidos a partir de pesquisas empreendidas acerca da diversidade sexual e de gênero, abrangendo assim uma grande variedade de tópicos e contextos investigados. Neles, além das relações e identidades sexuais propriamente ditas, verificamos uma complexificação na abordagem do tema, a qual passa a abarcar outros domínios da vida social, entre eles raça/etnia, classe e crença (cf. Fry, 1982a, 1982b; Guimarães, 2004; Perlongher, 1987; MacRae, 1990; Heilborn, 2004; Parker, 1991, 1994, 2002; Facchini, 2005; Díaz-Benítez, 2005; Lacombe, 2010, entre outros). Não obstante, percebemos nesses escritos a recorrência na contemplação de determinados cenários e estratos sociais. Exemplo disso está no fato de que parte considerável da literatura produzida sobre homossexualidades, travestilidades e transexualidades no Brasil tem como ambiente o contexto metropolitano, principalmente paulistano e carioca, valendo a ressalva de que, nos últimos anos, capitais como Belo Horizonte (Teixeira, 2009), Florianópolis (Henning, 2008), Fortaleza (Parker, 2002), entre outras, vêm despontando como locus de investigações socioantropológicas.

Entretanto, em virtude de o tema haver sido abordado quase que exclusivamente em cidades de grande ou médio porte, os estudos referentes às sexualidades "dissidentes" parecem indicar não apenas uma subárea no cômputo da Antropologia Urbana, mas também reeditar a noção segundo a qual uma paisagem mais diversificada no que diz respeito às sexualidades seria ela própria fruto da urbanidade ${ }^{3}$. Assim, foi no intuito de problematizar tal questão que cheguei a Catolé do Rocha - município localizado no Sertão do estado da Paraíba, próximo à divisa com o Rio Grande do Norte. À época da pesquisa, este município paraibano contava com uma população estimada em cerca de 30.000 (trinta mil) habitantes (IBGE, 2014). Considerada uma das principais cidades do Sertão do estado, abrigando indústrias de pequeno porte das áreas têxtil e calçadista, Catolé do Rocha tinha seu núcleo urbano constituído por 19 bairros e, em sua zona rural, dois distritos e 19 comunidades ou povoados.

Talvez valha a pena insistir que a escolha de Catolé do Rocha como locus de minha investigação obedeceu a critérios geográficos e socioculturais. É certo que autores como Peter Fry (1982a, 1982b) e Richard Parker (2002) pesquisaram a questão da homossexualidade, por

\footnotetext{
1 Sigla que representa Lésbicas, Gays, Bissexuais, Travestis, Transexuais e Transgêneros. Mais recentemente outras siglas vêm aparecendo em diversos meios de comunicação e informação, sendo uma das mais difundidas a LGBTQIAP+, que inclui pessoas que se reconhecem como queer, intersexuais, assexuais, pansexuais e outras (representadas pelo "+"). Mesmo reconhecendo a importância dos esforços dos movimentos políticos e também acadêmicos no sentido de conquistar maiores e melhores reconhecimento, respeito e representatividade em termos sexuais e de gênero, optei por manter ao longo do texto a sigla LGBT, procurando assim ser fiel ao momento em que a pesquisa foi realizada, ao nome do Grupo Fórum LGBT Catolé, à sua presença durante as conversas que mantive com Jonas e ao fato de que era essa a sigla constante do material bibliográfico do qual fiz uso durante a redação do presente trabalho.

2 A ideia surgiu durante uma conversa que tive com o professor Luiz Fernando Dias Duarte, que supervisionou a referida pesquisa. A propósito, importa registrar que, durante o período em que me dediquei a esta (entre os anos de 2013 e 2015), estive vinculado ao Programa de Pós-Graduação em Antropologia Social do Museu Nacional/UFRJ e contei com uma bolsa de Pós-Doutorado Júnior, concedida pelo Centro Nacional de Desenvolvimento Científico e Tecnológico (CNPq).

${ }^{3}$ Henning Bech (apud Eribon, 2008:33-34) parece corroborar tal constatação ao dizer que "'a cidade é o mundo social próprio ao homossexual, seu espaço vital. De nada serve objetar que muitos homossexuais viveram no campo. Na medida em que querem ser homossexuais, devem, em maioria, ir para a cidade, de uma maneira ou de outra...".
} 
exemplo, fora do eixo Rio-São Paulo. Ainda assim, o que sabemos a respeito desse assunto nos sertões do Brasil, entre sociedades camponesas ou no mundo rural? Não fosse o trabalho pioneiro de Paulo Rogers Ferreira (2006), no Brasil, e a consagrada obra de Miguel Vale de Almeida (1995), fruto de uma pesquisa conduzida em uma aldeia portuguesa, não estaríamos longe da verdade se respondêssemos "nada", ao menos se considerarmos a literatura lusófona. Desse modo, Catolé do Rocha apareceu como um lugar especialmente interessante por achar-se incrustado no Sertão nordestino, por não apresentar as características (morais, sociais, econômicas, culturais, etc.) frequentemente observadas (ou atribuídas às) nas grandes cidades do país. Nesse sentido, a crítica feita por Ferreira (2006) parece bastante percuciente e deve ser levada a sério, sobretudo por revelar aos cientistas sociais a necessidade de escaparmos a representações estereotipadas acerca dos homens e mulheres sertanejos(as) ${ }^{4}$.

Considerando este e outros fatores, procurei obter respostas para questionamentos do tipo: a) quais os mecanismos pessoais acionados por sujeitos gays, lésbicas, bissexuais, travestis $e$ transexuais em Catolé do Rocha no agenciamento de suas sexualidades, identidades e na condução de suas vidas?; b) tais mecanismos seriam os mesmos, similares ou completamente dessemelhantes daqueles acionados pelos sujeitos LGBT vivendo em espaços urbanos e/ou metropolitanos?; c) que tipo de relações sociais, familiares e afetivas era empreendido por estes indivíduos, considerando o papel desempenhado pelos familiares e vizinhos em meio a um cenário parcial ou completamente desprovido de anonimato?; d) seriam de natureza distinta nessa localidade as moralidades daquelas verificáveis em outros contextos sociais e, portanto, capazes de moldar outros padrões de sociabilidades homoeróticas e vivências sociossexuais?

Além do meu interesse em responder a estas perguntas, um outro e mais importante elemento acabou sendo determinante para a eleição de Catolé do Rocha como universo deste estudo. Em uma rápida consulta pela Internet ${ }^{5}$, descobri que, em 2010 , surgiu nessa cidade, graças a um evento realizado em parceria com o Centro de Referência Especializado de Assistência Social (CREASRegional), o Grupo Fórum LGBT Catolé, uma organização não governamental (ONG) instituída em torno dos ideais de "visibilidade" e "respeito" à "livre orientação sexual e identidade de gênero da população LGBT local", conforme texto divulgado pelo Fórum News Catolé (Ano II, $\mathrm{n}^{\circ}$ 3, julho/dezembro de 2012) ${ }^{6}$. Desde então, os integrantes do Grupo vinham desenvolvendo uma série de atividades, como a realização do Fórum Municipal de Saúde e Direitos Humanos LGBT (que teve quatro edições até o período que antecedeu o início de minha pesquisa); elaboração de projetos para a captação de recursos objetivando a realização de novos eventos; promoção de oficinas pedagógicas sobre diversidade sexual em escolas municipais e estaduais, tendo como público-alvo estudantes e educadores do município; e até mesmo a organização de uma mostra de cinema com temática LGBT em praça pública.

Tendo como uma de suas principais bandeiras o combate à homofobia na região, o Grupo Fórum LGBT Catolé (doravante referenciado apenas como Grupo Fórum), em parceria com o CREAS, empreendeu uma pesquisa, junto à população LGBT local, no intuito de conhecer suas "experiências" e "opiniões". Como parte da pesquisa, foi elaborado um questionário de perguntas distribuídas em quatro "blocos". No primeiro, referente a sexualidade e sociabilidade, foram exploradas questões de cunho pessoal e afetivo. No segundo, sobre engajamento político, buscouse averiguar a participação do(a)s entrevistado(a)s em movimentos sociais. No terceiro, as/os pesquisadoras/es buscaram informações relacionadas a experiências de violência e discriminação e, no quarto bloco, procuraram traçar um perfil pessoal e socioeconômico das pessoas ouvidas (estas informações constam do Fórum News Catolé, Ano I, nº 1, de julho/dezembro de 2011).

\footnotetext{
4 Importante registrar que nos últimos anos vêm se avolumando publicações resultantes de estudos realizados nos sertões do Brasil acerca da diversidade sexual e de gênero. Os trabalhos de Gontijo (2011, 2012, 2013), Marques (2011) e do próprio Ferreira (2007) são exemplos disto.

${ }^{5} \mathrm{Na}$ verdade, inicialmente pensei em desenvolver a pesquisa em Cajazeiras, município também situado no Serão da Paraíba, onde existia uma das ONGs LGBT mais antigas do estado. Contudo, não encontrei informações mais detalhadas e consistentes relacionadas a este coletivo.

6 Todos os números do Fórum News Catolé podem ser acessados através do Blog do Grupo Fórum LGBT Catolé: http://forumlgbtcatole.blogspot.com/
} 
O aparecimento de uma associação como o Grupo Fórum parecia indicar a crescente difusão no Brasil de organizações governamentais e não governamentais surgidas a partir da consolidação de políticas públicas voltadas para a população LGBT no país. Parecia ser também um indicativo da maior visibilidade e politização do debate em torno da diversidade sexual e de gênero e do recrudescimento das demandas pelo reconhecimento de sujeitos LGBT. Todavia, se, por um lado, tal fenômeno sugeria um espraiamento macrossocial das políticas vinculadas às sexualidades, identidades e relações de gênero no país, por outro lado restava saber o grau de intensidade $e$ propagação que estas políticas apresentavam para sujeitos específicos, moradores de determinadas localidades, como Catolé do Rocha.

Nesse sentido, portanto, conferi especial atenção às biografias e trajetórias dos atores ouvidos em sua conexão com diversos marcadores sociais (socioeconômicos, morais, religiosos, políticos, sexuais, de gênero e raça) e com as relações mantidas pelos mesmos com amigos, familiares $e$ demais afetos. Obviamente, como mostrarei adiante, as referidas especificidades não foram tomadas como se deslocadas de fatores sociais mais amplos que extrapolavam a realidade local, sendo consideradas em sua articulação com políticas, discursos e imagens regionais e nacionais. Sendo assim, busquei contribuir, a partir de um estudo de caso, para o deslindamento de cenários outros nos quais são vividas as sexualidades no Brasil, de modo a descristalizar estereótipos frequentemente associados aos modos de vida sertanejos. O que virá a seguir, a partir do próximo tópico, é um primeiro exercício de sistematização e análise de uma pequena, porém significativa parte do material etnográfico obtido/coconstruído durante o tempo em que estive em Catolé do Rocha. Para tanto, recorrerei largamente à história de vida e às palavras de um dos seis integrantes do Grupo Fórum, interlocutor/amigo que me fez atentar para algumas dimensões não apenas da realidade local na qual me inseri, mas da própria existência humana ${ }^{7}$.

\section{Jonas e o Grupo Fórum LGBT Catolé}

Tão logo cheguei em Catolé do Rocha, em abril de 2014, procurei os membros do Grupo Fórum, interessado inicialmente em conhecer a história de sua formação $e$ as atividades desenvolvidas em seu âmbito ao tempo da pesquisa. Devo dizer que não encontrei dificuldade alguma, uma vez que, em questão de poucos dias, eu já havia sido apresentado aos seis membros (cinco homens gays e uma mulher transgênero) do Grupo Fórum. Um deles era Jonas, um estudante universitário de 31 anos de idade, desempregado, nascido em Catolé do Rocha, que se tornou membro do Grupo em 2011. "Sempre gostei de participar de grupos com certas problemáticas, de estar num ambiente com pessoas iguais à minha pessoa. A curiosidade de trabalhar com o povo, na verdade. Esse calor humano... É um Grupo que é a minha cara, né? Então, foi todo esse conjunto que me atraiu ao Grupo", disse-me ele.

O trabalho desenvolvido pelos integrantes do Grupo Fórum era de caráter voluntário, ou seja, Jonas, bem como seus companheiros, não recebia remuneração alguma. Na verdade, a escassez ou total ausência de recursos comprometia a sobrevivência da ONG, tanto quanto o grau de engajamento de seus integrantes, que, para proverem suas necessidades materiais, precisavam exercer (quando podiam) outras atividades remuneradas. Recursos para o Grupo, quando obtidos, eram por meio de projetos elaborados por outras instituições governamentais ou não governamentais do município de Catolé do Rocha ou de outros municípios paraibanos (como o MEL - Movimento do Espírito Lilás, sediada em João Pessoa, e a AHCG - Associação dos Homossexuais de Campina Grande) - que convidavam os membros do Grupo Fórum para participarem de algum evento —ou graças à contribuição de alguma figura pública, geralmente um político local. Outra parceria importante se dava com duas ONGs que atuavam em Catolé do Rocha, a ONG canadense PDA - Estrela da Manhã, dedicada à assistência a crianças carentes, e a Xique-Xique, voltada para o trabalho com comunidades quilombola, à preservação de um sítio

\footnotetext{
7 Devo insistir aqui na ideia de um trabalho etnográfico "coconstruído", pois penso os interlocutores como coautores da pesquisa. Considero pertinente também enfatizar que as palavras e formulações discursivas de Jonas aparecerão ao longo do texto exatamente como aquilo que são: texto. Portanto, não as transcreverei como se foram citações à parte ou mero complemento da minha argumentação.
} 
arqueológico e do meio ambiente. Importante destacar ainda a colaboração com a Universidade Estadual da Paraíba, que tinha um campus no município.

Desde o ano de 2010, quando o Grupo Fórum surgiu, até 2014, quando de minha primeira visita a Catolé do Rocha, dentre as atividades e/ou eventos até então promovidos pelo Grupo destacavam-se a Semana de Enfrentamento à Homofobia, no mês de maio; palestras e atos públicos contra a transfobia; distribuição de preservativos, gel lubrificante e panfletos informativos durante o pré-carnaval. Para Jonas, tais atividades representavam uma conquista: "quem imaginaria que tivesse um grupo de gays que levantassem a bandeira, com héteros e outros gays que atiram pedras? Cada lado tem uns atirando, tem uns criticando. E a gente... juntos, mobilizados em torno do Grupo, já é uma conquista. Porque, durante esses percursos todos, quem imaginaria? Porque ainda há suspiros de tristeza do Grupo se acabar". Isto porque, de acordo com Jonas e outros interlocutores, eram poucos aqueles e aquelas que participavam das reuniões $e$ outros eventos promovidos pelo Grupo. "Muitos gays querem participar do Grupo por causa de uma viagem, por causa de uma festa. Na hora do trabalho não querem", afirmou Jonas.

\section{Instantâneos do universo LGBT local, segundo Jonas}

O que dizer acerca das vidas de pessoas gays, lésbicas, bissexuais, travestis e transgêneros em Catolé do Rocha? Para tentar responder a esta pergunta, além da observação, procurei ouvir o que os meus interlocutores pensavam a respeito. Para Jonas, uma das marcas da população LGBT local era o "individualismo": "a população LGBT é individualista, cada um no seu quadrado. Tem aquela divisão de classes, de "Eu tenho mais condições, então eu posso mais do que aquele outro gay que tem a classe baixa'. Se eu sou um gay que vivo me prostituindo, aquele outro gay, que vive na visão de classe alta, [diz]: 'Eu não posso me misturar com o outro, porque o outro é baixo'. Então, é uma visão muito individualista. Eu vejo dessa forma, cada um no seu quadrado".

Além do "individualismo" e do classicismo, apontados por Jonas como fatores responsáveis por fissuras nas relações entre sujeitos do universo LGBT em Catolé do Rocha, um outro elemento evocado por ele referia-se à prostituição e à violência. De acordo com Jonas, alguns gays e, sobretudo, travestis/transexuais se prostituíam, geralmente na área central da cidade. De fato, durante minhas estadas em Catolé do Rocha, fui algumas vezes ao local descrito por Jonas. Confirmando seu discurso, observei jovens gays e transexuais, cuja interação aparentemente envolvia jocosidade, afeto, solidariedade, mas também tensões. Nas palavras de Jonas, "eles ficam todos juntos, mas sempre há aquela divergência. Uma hora vão todos se relacionar no mesmo espaço, lá num canto afastado do Centro da cidade; e tem dia que estão todos brigando: 'Porque eu sou travesti, eu tenho peito', ou 'Eu sou transexual, sou toda cirurgiada, tô toda feminina e você é gay e não consegue nada', ou 'Eu sou gay, então você só consegue um homem porque você está comigo". Além desse tipo de disputas, que algumas vezes culminava em conflitos abertos e violentos (isto é, terminavam desembocando em agressões verbais ou físicas), havia também segundo Jonas e outros interlocutores - casos de investidas motivadas por homo/transfobia, potencializadas pela situação ou prática prostitutiva. Quanto à autoria desses ataques, tratava-se geralmente de um transeunte do sexo masculino ou de um cliente das travestis ou transexuais ${ }^{8}$.

Algo que também me chamou a atenção ao longo do trabalho de campo, sendo reforçado pelo discurso de Jonas e de outros integrantes do Grupo Fórum, dizia respeito ao L da sigla LGBT, ou, melhor dizendo, à ausência de mulheres lésbicas tanto no Grupo quanto nos espaços públicos da cidade. Pretendo discutir mais detalhadamente este assunto em outro momento, porém, considero importante evocar as palavras de Jonas, que, no intento de explicar tal fenômeno, afirmou que "elas [mulheres lésbicas] tentam se portar dentro da sociedade. Elas têm medo do que a sociedade vai falar, mesmo [a sociedade] sabendo que elas já são [homossexuais]. Mas não se expressam, muitas não se expressam afetivamente. Outras sim, se beijam, se tocam, aquela coisa toda. Têm uma afetividade. E outras têm vergonha, têm medo, por causa da família, por causa do

\footnotetext{
8 Durante o tempo em que permaneci em Catolé do Rocha, a notícia era de que havia quatro travestis ou transexuais na cidade. Tive a oportunidade de aproximar-me mais de apenas uma delas, integrante do Grupo Fórum, que aceitou ser entrevistada por mim.
} 
filho, por causa da sociedade". Mesmo admitindo haver um número maior de mulheres lésbicas do que de homens gays em Catolé do Rocha, Jonas dizia que, "na verdade, algumas estão fechadas" e "agora está aparecendo mais gay. Os gays estão aparecendo mais, principalmente os mais novinhos, [de] sete, oito, nove anos", apontando para transformações no perfil do público LGBT, notadamente no que se refere aos marcadores de gênero e geração em seu cruzamento com o fator visibilidade no espaço público.

Outro tópico abordado durante meus encontros com Jonas dizia respeito aos locais de sociabilidade, isto é, aos espaços de encontros, paqueras e outras interações de pessoas LGBT em Catolé do Rocha. Diferentemente do que se pode encontrar nas grandes metrópoles brasileiras, não havia ali nenhum bar, boate ou qualquer outro local diretamente voltado para um público LGBT. Assim, praças públicas, bares, pizzarias, sorveterias eram frequentadas por um público "misto", segundo Jonas. Porém, ele fazia uma ressalva: "mas assim, na pizzaria é uma coisa muito mascarada, porque há os gays que vão, mas são gays muito restritos; eles não se portam extravagantemente, eles são fechados. Não dá nem para perceber muito que são [gays], porque é uma coisa muito fechada". Ao contrário dos "gays muito restritos", aqueles outros, que se portavam "extravagantemente", "podem até ter condições de ir para a sorveteria, mas eu não vejo numa pizzaria, numa sorveteria. Quando se juntam, é para comprar uma bebida e ir para a praça, tomar essa bebida reservada; fazem uma balada reservada. Os gays de classe... financeiramente mais alta, eles... é misturado com a população, porque eles são vistos como pessoas normais, com quem eu posso conviver sem nenhum problema. Mas, se for uma bicha afetada, aí eu não posso conviver, "porque ela chama, ela fecha demais!"”.

Alguns dos locais onde eram realizadas as "baladas" se destacavam, como o Cantinho da Seresta e, sobretudo, o Clube AABB, espaço que abrigava o "Créu", nome pelo qual era conhecida uma das "baladas" mais populares da cidade. Entretanto, segundo Jonas, muitas pessoas evitavam o "Créu", "porque hoje é visto como uma orgia lá. O que você pode ver assim é um beijo gay, um sarro de héteros; num lugar reservado assim, escuro, alguém se pegando... Rola muita droga também, muita prisão também, briga demais. Dá de tudo: dá lésbicas, dá héteros, travestis, transexual, gays, prostituta, de tudo. Tudo dá lá dentro, tem de tudo".

$\mathrm{O}$ aspecto referente à sociabilidade envolvendo sujeitos LGBT mantinha, na apreciação de Jonas, estreita ligação com a maneira como outros moradores de Catolé do Rocha lidavam com este segmento populacional, o que também incidia, direta ou indiretamente, no grau de legitimidade do Grupo Fórum, de modo que não se poderia afirmar que foram raros os episódios em que uma personalidade pública, como um político ou empresário, se negou a contribuir financeiramente com o Grupo Fórum quando da tentativa de organização de algum evento ou atividade voltada para a população LGBT local. De acordo com Jonas, "existem os gays que são mais da noite, que vão pra rua. Tem alguns gays que aprontam muito na sociedade. $\mathrm{E}$, os que não são, levam a culpa também. Muitas vezes têm escândalo, briga por causa de homem, por causa de outra besteira, aquela coisa toda. E, os que não são escandalosos, levam a culpa. E a sociedade, você sabe, é uma faca de dois gumes. Sempre julga, sempre briga. Aí vai o Grupo LGBT pedir um patrocínio, uma ajuda pra ajudar num fórum, num seminário, numa coisa desse tipo, e às vezes não dá por causa dos olhares, por causa dos outros".

\section{A vida íntima de Jonas}

A exemplo do que se deu com outros interlocutores, um dos tópicos abordados durante os meus encontros com Jonas referiu-se à sua vida pessoal, à sua trajetória biográfica, a começar por sua infância, tema que sempre procurei abordar com praticamente todos os sujeitos que conheci $e$ com quem convivi nas pesquisas que realizei. No caso de Jonas, sua memória narrada o levava a uma infância em que o lúdico se imiscuía com noções de gênero, sexualidade e sofrimento: "Na minha infância fui muito de brincar de boneca, fui muito de fazer as roupinhas das bonecas de minhas amigas, fui muito de apanhar porque minha avó abria a bolsa e encontrava retalhos" (das roupas de boneca confeccionadas por ele). Em contrapartida (ou em consequência disso), Jonas igualmente recordava um momento "pesado": "Teve um momento assim pra mim muito pesado", no período em que ele estava aprendendo a andar de bicicleta e seu pai exigiu do filho um "jeito 
másculo" de se portar, algo a que Jonas não correspondia. Por conta disso, ele afirmou ter apanhado muito, que sempre foi "violentado". "Sempre tinham algo a colocar a culpa em mim. E não colocavam a culpa no outro, mas em mim. Porque eu acho que, desde pequeno, já sentiam a essência [aqui Jonas se referia direta, ainda que um tanto eufemisticamente, à sua sexualidade]. Agora assim, do que eu lembro da minha infância, eu acho que um ponto marcante: eu estava na casa com ela [sua avó materna, que o criou], de um compadre da minha avó, e eu fui até o muro. Pela minha lembrança, eu lembro que era um boneco e faltavam os braços. Mas era uma boneca, não era um boneco. Aí fui pra casa desse jeito". Jonas prosseguiu sua narrativa, dizendo que levou a boneca consigo para casa. Lá chegando, sua avó o fez voltar à casa do compadre e devolver a boneca, mesmo sendo um objeto largado no lixo. Jonas disse que isso o marcou profundamente, acrescentando que a forma como foi educado pelos avós e por um dos tios - educação, segundo ele, pautada na honestidade, na retidão, conferiu-lhe "traços masculinos". "Na verdade, me vejo nesse ponto mais hétero, em termos de caráter", disse ele, citando o avô materno e dois tios como "figuras de homem" importantes em sua vida, responsáveis pela formação de seu caráter. Quanto ao pai, "eu não tive figura de pai, ele não foi apoio em nenhum momento".

Além dessas lembranças de infância, uma outra, evocada por ele, referia-se aos olhares dos outros. Algumas pessoas, fora do contexto familiar, "olhavam com olhares diferentes, mas sempre calados. Só observando. Às vezes não queriam que eu brincasse com alguém. Às vezes eu ia brincar com o meu amigo, dentro da casa da vizinha, com os carrinhos dele, mas, por outro lado, eu já ia com segundas intenções. E a mãe dele já tinha dúvidas, né? Porque ela sempre dizia assim: 'O que é que vocês estão aprontando aí embaixo?'. E eu já percebia, mesmo na minha infância, que ali naquele 'O que é que vocês estão fazendo?', tinha um porquê a mais". Outras experiências de discriminação, porém, bem mais contundentes que esta, viriam a marcá-lo.

Jonas foi criado pela avó materna. Entretanto, quando nos conhecemos, ele vivia com a mãe - seus pais eram separados havia muitos anos - uma senhora aposentada de 65 anos, e seu único irmão, menor que ele. Com relação ao pai, Jonas não escondia certo desconforto ou mesmo desprazer em falar a seu respeito. "Eu posso dizer um pouco sobre meu pai. Às vezes que eu ia lá, onde ele morava, da última vez ele se mostrou muito distante. E eu já estava percebendo que tinha algo a ver com minha sexualidade. Mas não foi nada aberto, ele não comentou nada. Mas se mostrou... deu aquele gelo. Que toda vida que eu ia à casa dele, ou encontrava ele por lá, ele se mostrava muito afetivo para comigo. E, dessa última vez que eu fui, ele se mostrou muito afastado, distante". No mesmo dia e no mesmo local em que Jonas teve esse encontro com o pai, uma outra situação, desta vez envolvendo uma tia de seu pai, o marcou profundamente, a ponto de Jonas recordá-la com emoção e vivacidade: "Nesse mesmo dia ela pediu para falar comigo reservadamente. Entrei na casa dela, ela disse: 'Meu filho, eu quero saber se você é aquelas coisas' - expressão dela, que ela não tem formação. Eu disse: 'Não, tia' - Mesmo eu omitindo, né? - . Eu disse: 'Não, tia. É porque eu tenho facilidade, eu tenho amizade com todo mundo'. 'Não [prosseguiu a tia de Jonas], porque se você for aquelas coisas, eu ia mandar você sair da minha casa agora, porque isso não é papel pra homem'. Às vezes eu vejo [a atitude da tia] como [resultado da] falta de informação, de conhecimento, né?".

"Depois", prosseguiu Jonas, "não sei se minha tia comentou alguma coisa com ele [com seu pai], mas os rumores já estavam chegando na localidade onde ele morava, com quem eu andava, a forma como eu dançava, a forma como eu convivia com as pessoas; pessoas que eu acho que viram uma fuga de um beijo no meio de uma festa, e aquela coisa toda". Após essa exposição de sua vida sexual (uma espécie de "saída do armário" involuntária, compulsória), Jonas teve não apenas sua relação com o pai comprometida, esfriada, mas também com muitos de seus familiares, incluindo tios e primos, "porque descobriram. Mas não deixei de ser eu por causa disso, estou vivendo do mesmo jeito", disse ele. "De casa para a rua eu já apanhei verbalmente, fisicamente, e assim por diante... Coisas drásticas, passadas". Quanto ao seu irmão, a situação era mais complicada: "Ele já foi mais escandaloso para com a minha sexualidade, mas hoje ele é mais ou menos. Ele gritava palavras horrorosas comigo, na minha antiga casa, no meio da rua, fazendo escândalos. Âs vezes ele ainda faz alguns escândalos, mas não é tantos. Eu não posso ter amizade com um homem, porque ele [o irmão de Jonas]" deduz e insinua que ele está se relacionando 
afetiva e sexualmente com o referido homem. "É difícil", disse Jonas, depois de mostrar marcas em suas pernas, vestígios de ferimentos causados por uma cadeira lançada contra ele pelo irmão, acrescentando ainda que sua mãe ficava "doente" em virtude da relação conflituosa entre os filhos?.

Por falar na mãe e na equação afetiva/relacional em que sua sexualidade estava implicada, Jonas disse que por muito tempo imperaram o silêncio e a negação ("Eu cheguei a negar três vezes a minha homossexualidade"). Entretanto, havia o mundo, a rua, as pessoas, "a sociedade comentando, criticando", o que acabou chegando "aos ouvidos dela". Assim, no ano de 2014, pouco antes, portanto, do meu primeiro encontro com ele, Jonas decidiu "confessar-se": "Eu cheguei e disse: 'Mãe, eu sou homossexual'". Ela então lhe disse: "Eu já estava esperando, meu filho, que você abrisse a sua boca, dissesse com suas palavras'. E, graças a Deus, a gente se dá super bem". Jonas afirmou que sentiu a necessidade de contar, de confessar para a mãe que era homossexual, pois, segundo ele, não era possível viver nessa "amargura" para sempre: "Eu digo: "Eu tenho que contar, porque eu vou envelhecer, eu vou envelhecendo e vou vivendo nessa amargura... Não dá! Então, nem que eu não conte tudo pra ela da minha vida, mas, se eu não tiver uma boa relação com ela dentro de casa, como é que eu vou viver? Eu vou procurar todo dia sair de casa pra fugir dela? Porque eu mostro pra ela quem eu sou dentro de casa. Eu sou extrovertido, eu sou brincalhão, eu 'fecho' dentro de casa normalmente. Entre aspas, porque tem coisas que não dá pra fazer" ${ }^{10}$.

A respeito ainda de sua sexualidade, Jonas e eu conversamos sobre sua trajetória sexual e afetiva, tema que acabou nos levando de volta à sua infância. "Desde pequeno eu sentia a essência, mas não me aceitava. Na infância eu tinha minhas coisas [aventuras sexuais], mas não queria me aceitar. Dizia que estava fazendo, mas não era o que eu estava pensando. Não queria aceitar. Aí comecei a me aceitar a partir dos 18 anos, mesmo com alguns transtornos, com alguns contratempos; com a visão da sociedade, as críticas, as piadas, a violação física, às vezes. Eu cheguei a ser agredido". Contudo, muito antes desse período de aceitação de si, quando tinha apenas oito anos de idade, Jonas experimentou sua primeira relação sexual "com um amigo, um vizinho"; depois com primos. "Eu quem ia atrás. Eu era uma criança atrevida. Eu tinha aquele desejo, aquela ansiedade. Não queria aceitar, mas era aquela contradição na cabeça. Não aceitava, mas, de um lado da mente, já vinha dizendo que sim. Gerava um conflito. Porque assim, foi também naquele período de seminários, de vida religiosa. Porque eu entrei no Seminário porque eu pensava que eu poderia mudar"11.

\footnotetext{
9 Diversas passagens da narrativa de Jonas me remeteram às considerações de Júlio Simões (2004:433), quando este nos diz, por exemplo, que "[n]as narrativas de coming ouf', em que os personagens se esforçam para dar um sentido ao seu desejo sexual por meio de um relato de vida, o preconceito e o estigma contra a homossexualidade tendem a se constituir o grande oponente, que cria a ambiência social na qual a orientação sexual é vivenciada como uma fonte de aflição $e$ sofrimento. Em contrapartida, se produzem as bases para uma 'história boa' ou 'acompanhável'”.

${ }^{10}$ Ao evocar o tema "confissão da sexualidade", vale recordar as palavras de Foucault: "Por que dizemos com tanta paixão que somos reprimidos? Por que hoje em dia nos culpamos tanto por ter outrora feito do sexo um pecado?" (Foucault, 1988:14). Tal pergunta não passa de uma retórica que distorce a verdade dos fatos, de acordo com Foucault. Na verdade, para ele o que é próprio das sociedades modernas não é a condenação do sexo ao obscurantismo, mas sim a obsessiva devoção a "falar dele sempre, valorizando-o como 'O' segredo" (Foucault, 1988:36). Nesse sentido, o sexo foi colocado como aquilo cuja verdade deveria ser confessada. "A confissão da verdade se inscreveu no cerne dos procedimentos de individualização pelo poder. É na confissão que se ligam a verdade e o sexo, pela expressão obrigatória e exaustiva de um segredo individual. É a verdade que serve de suporte ao sexo e às suas manifestações" (Foucault, 1988:58).

${ }^{11}$ Jonas chegou a morar, durante pouco mais de dois anos, em outras duas cidades da Paraíba. Durante esse período, ele foi seminarista e pretendia tornar-se padre. "Quando eu entrei no Seminário, eu tinha a ideia de que eu ia mudar. Mas isso não me impediu, porque houve coisas, não dentro das portas, mas fora das portas, com pessoas da sociedade, da comunidade". Quando o conheci, porém, Jonas se dizia umbandista: "Hoje eu sou da Umbanda, hoje eu sou umbandista. Porque antes eu fui doutrinado, educado como católico romano. E já fiz visitas antes a igrejas protestantes, mas não me sentia bem. E hoje, por rumores da vida, me encontro como umbandista. Eu entrei no terreiro dia 30 de setembro do ano passado [2013], [o] que para mim foi importantíssimo, foi o ápice na minha vida". Segundo Jonas, não havia travestis frequentando o terreiro, mas havia gays: "Tem. Mas aqui, por ser tão tradicional, por eles terem uma visão tão tradicional que nós recebemos certos recados (tanto das matérias, como também das entidades), que a gente não pode estar assim, indo a todo espaço, andando com todo mundo, se vestindo como mulher, eles não querem. Nem as entidades e nem a matéria".
} 
Mas, afinal de contas, o que Jonas quis um dia mudar? Sua sexualidade, a homossexualidade, o que, em suas palavras, "antes eu via só como uma parte erótica, só como a relação de dois homens, no sentido passivo e ativo. Mas eu acho que vai além de uma certa afetividade, de um certo companheirismo, de uma certa fraternidade, de uma certa ligação de duas pessoas. Vai além disso. Pra mim é um mistério até de explicar e falar sobre a homossexualidade. É uma relação muito íntima, é o ser diferente dentro de uma sociedade machista, heterossexual". Ou seja, a noção construída por Jonas acerca da homossexualidade envolvia, inapelavelmente, o preconceito, a discriminação, o estigma e uma outra noção, a de relacionalidade. Porém, o que estava em jogo neste tipo de relação? "Eu vejo como aquele personagem do seu livro, como sofrimento $^{12}$. Eu não vou dizer como ele, que tenta mascarar, que diz que não sente nada. Eu sinto, que eu sou humano e sinto. Eu apenas concordo na parte que é um sofrimento, porque... e amarguras da vida. Não sei se, com essa pessoa que eu estou agora, eu vou me completar. Nessas minhas idas e vindas já sofri demais verbalmente, fisicamente... desilusões. Então, me tornou uma pessoa desconfiada... e à procura de fugas, muitas vezes. Tô com ele, mas, se aparecer outra pessoa e a outra pessoa... Eu já tô de olho, ou chego a perguntar. Sou desse jeito. As idas e vindas amorosas me tornaram essa pessoa. Eu sou um pouco pé atrás, porque eu já sofri demais. Porque não encontrei nessas pessoas o que eu queria: a confiança, o companheirismo, essa confidência, todo um conjunto de relacionamento a dois. Eu não encontrei. Sempre faltava alguma coisa. E eu quero tudo isso numa pessoa só. Que eu não quero uma pessoa passageira na minha vida. Eu quero uma pessoa fixa. É por isso que às vezes eu sou uma pessoa assim, desiludida".

Além da dimensão afetivo/sexual, constante da economia existencial elaborada por Jonas, havia também, atrelado (ao menos circunstancialmente) à narrativa acerca de sua sexualidade, um componente relacionado à questão de gênero: "Eu posso até dizer como eu me vejo na verdade, porque o gay não poderia dizer que se vê como uma mulher. Mas tem momentos em que eu me vejo como mulher. Me vejo, penso como mulher, ajo às vezes como mulher". Dizendo ser "a menina da casa", por se dedicar aos afazeres domésticos, Jonas construiu para si um alter ego feminino, por ele nomeado Glória Sanders, uma "senhora fina e educada", segundo ele, que aparecia, vez ou outra, em alguns eventos promovidos pelo Grupo Fórum. "Eu fiz dessa forma, eu criei, elaborei ela dessa forma, como uma senhora fina, educada. Eu acho que é a minha essência. Eu posso ter meu jeito fechoso, brincalhão, mas eu não me vejo como travesti, porque não é minha essência. Minha essência é outra, não é uma essência vulgar. Não quero mostrar essa visão feminina, de uma travesti, de uma transexual, de uma forma vulgar".

Entretanto, mesmo ratificando este anunciado relativo à sua "essência não vulgar" feminina, em outras passagens de seu discurso Jonas caminhava rumo a um certo tipo de masculinidade, já que, segundo ele, "eu não tenho essa prática de estar gritando no meio da rua, de estar fazendo certos vulgarismos que alguns gays machos têm o costume de fazer. Eu não, eu me vejo um pouco assim, masculino, no modo de se portar em certos locais, conversar com alguém. Porque às vezes tem homens que têm atração por gay e não gostam. Aí, às vezes, para não perder a amizade, eu tento me portar à altura. Eu procuro também ser aceito. Porque quando alguém diz que é gay e aceita outro gay, mas não aceita que o gay seja afeminado, dói". Assim, o "ser aceito" para Jonas passava inevitavelmente pelo marcador de gênero, significando gestionar uma modalidade de comportamento que evitasse ou ao menos reduzisse as probabilidades de ele vir a sofrer algum tipo de violência homofóbica. "O ruim [de ser homossexual] só são as críticas, a violência física, às vezes. Agora, graças a Deus, eu não sofri mais fisicamente, mas verbalmente demais: os olhares, a dificuldade de emprego, esse é o lado ruim. E me chamam de gay pobre, gay lascado, bicha velha, e outras expressões. Minha preocupação é porque tem gays como eu que estamos sentindo agora essa necessidade, essa dificuldade por causa dos empregos. O olhar, a crítica... principalmente eu, que sou professor, os pais ficam criticando, com aquele olhar meio assim... ficam se questionando: 'Será que eu devo colocar ele pra ensinar meu filho?'. [Ficam] com aquele medo [de] que ele [o filho] adquira nosso comportamento; que a gente seja um erro para a sociedade, seja algo

\footnotetext{
12 Jonas se refere aqui a um livro de minha autoria, fruto de uma pesquisa anterior, com o qual lhe presenteei. Ele alude a um de meus interlocutores, para quem amar era sinônimo de sofrimento.
} 
complicado para a sociedade. Eu gostaria que tivessem mais informações, abertura de mentalidade. É triste esse comentário, mas é o que eu quero dizer".

\section{A via-crúcis de Jonas}

"É triste esse comentário, mas é o que eu quero dizer".

Decorridos alguns anos desde que estive em Catolé do Rocha e conheci Jonas, ainda penso em sua história, nas suas palavras, em seus itinerários. Em alguma medida, Jonas e eu nos tornamos amigos, de modo que nos encontrávamos em diversos momentos e espaços, inclusive em algumas noites de sábado no "Créu". Penso muito também no que os outros (entre os quais integrantes do Grupo Fórum, mas não só) disseram a seu respeito, o que foi importante, porque foi graças a estes outros que pude me dar conta dos silêncios de Jonas, daquele tipo de silêncio de que trata Michael Pollak (1989), um silêncio que diz mais do que oculta, silêncio estratégico graças ao qual é possível guardar nos porões da memória lembranças traumáticas ou vergonhosas. Quero refletir sobre isso.

É preciso lembrar que Jonas, além de homossexual, era umbandista, detalhe para o qual não conferi o devido destaque até o momento. Ele também era negro, o que também não disse. Assim, se Jonas podia transitar, situacionalmente, pelo feminino e pelo masculino - ilustrando assim a plasticidade do gênero - através do olhar-discurso de outrem, sua identidade/subjetividade/pessoa era objeto de racialização (embora ele nada tenha dito a respeito de qualquer episódio discriminatório motivado por sua crença religiosa ou pela cor de sua pele). Além disso, os marcadores de classe e geração eram acionados para estigmatizá-lo, de modo que, por meio da fala-ato dos outros, ele se via ocupando, também situacionalmente, os lugares de "bicha velha" e "pobre". Ou seja, o corpo, a identidade e a subjetividade de Jonas eram atravessados de maneira aguda pelos marcadores de gênero, sexualidade, crença, geração, classe e raça.

Poder-se-ia dizer que tal fenômeno se passa, de um modo ou de outro, com qualquer um de nós, o que é verdade, e é justamente por essa razão que o caso ilustrado por Jonas deve nos interessar, inquirir e inquietar. No que diz respeito ao fator gênero, a relação estabelecida por meu interlocutor com o feminino e o masculino estava longe da linearidade ou do simplismo. A "fineza" de Glória Sanders era tão valorizada quanto o "caráter" do eu masculino de Jonas. Todavia, isso não significa que esse trânsito valorativo se dava na ausência de conflitos. Ora, todas as vezes em que Jonas trouxe à tona a persona de Glória Sanders, ele expressou ao mesmo tempo fantasia, desejo e medo. A fantasia e o desejo de tornar-se mulher, investindo no processo de transexualização. Entretanto, o medo sempre o impedia de fazê-lo. Mas de qual medo estamos falando? $\mathrm{O}$ medo da rejeição, da discriminação, o medo da injúria ${ }^{13}$. Tal medo não era sem razão. O próprio Jonas narrou episódios de violência homofóbica, o que muito tinha a ver com o seu gênero, ou, se preferirmos empregar aqui uma expressão butleriana, com sua performance de gênero (Butler, 1990). A "feminilidade" reconhecida - para não dizer (auto)atribuída - por Jonas era não apenas notada, mas objeto de acusação, inclusive por parte de pessoas próximas a ele, com quem conversei. Para elas, Jonas não se portava bem, era "escandaloso", isto porque bebia, dançava solto em público, em suma, porque "fechava", como ele mesmo dizia. Assim, o veredicto estava dado: Jonas era culpado. Culpado por não saber "viver em sociedade", estava sem emprego, era alvo de violência/discriminação, vivia "desiludido" no amor ${ }^{14}$. Para complicar ainda

\footnotetext{
${ }^{13}$ A injúria, segundo Eribon (2008:28), "me faz saber que sou alguém que não é como os outros, que não está na norma. (...) Aquele que lança a injúria me faz saber que tem domínio sobre mim, que estou em poder dele. E esse poder é primeiramente o de me ferir. De marcar a minha consciência com essa ferida ao inscrever a vergonha no mais fundo da minha mente. Essa consciência ferida, envergonhada de si mesma, torna-se um elemento constitutivo da minha personalidade".

${ }^{14}$ A propósito deste enunciado relativo à questão da culpa e da violência "justificável", entrevistando profissionais dos Centros de Referência Especializados de Assistência Social (CREAS) Regional e Municipal, ouvi relatos de que a violência (psicológica, verbal e/ou física) constituía um fato mais comum na vida de jovens e adultos gays e que o mesmo não se dava com tanta frequência no caso de garotas e mulheres lésbicas. As profissionais com quem conversei interpretavam como episódios de violência xingamentos, ameaças de morte e expulsão de casa por parte dos pais de sujeitos LGBT. Depreendi dos discursos das pessoas ouvidas uma espécie de "culpabilização" de jovens gays e transexuais, uma vez que, segundo aquelas, estes agentes, ao não terem uma postura "discreta", acabavam por atrair para si uma sorte de atos
} 
mais as coisas, Jonas era umbandista. Ter aderido a esta religião foi importante, não apenas para sua espiritualidade, mas para sua aceitação de si, de modo que para ele a Umbanda foi libertadora. Por outro lado, à sua adesão religiosa se somavam, como elementos complicadores, sexualidade e gênero nos discursos daqueles que o rotulavam. O fato de Jonas ser negro e pobre em nada contribuía para tornar sua vida menos dura.

Teoricamente falando, penso ser rentável ler este caso à luz das noções de interseccionalidade (cf. Brah; Phoenix, 2004; Piscitelli, 2008; McClintock, 2010) e diferença (Brah, 2006), afinal, como já foi dito, era notória aqui a presença dos marcadores de sexualidade, gênero, crença, classe, raça e geração, os quais apareciam articulados, dependendo da situação, dos atores envolvidos e dos interesses, desejos, receios ou mesmo constrangimentos de Jonas. Nesse sentido, são oportunas as palavras de Adriana Piscitelli (2008:266), para quem tais marcadores (categorias) funcionam como "ferramentas analíticas" graças às quais podemos "apreender a articulação de múltiplas diferenças e desigualdades". À primeira vista, poderíamos afirmar que Jonas acionava (em graus variados, às vezes até silenciando, e de acordo com cada situação interacional) estes diversos marcadores, combinando-os de modo a construir uma narrativa por meio da qual ele elaborava uma identidade coerente, num processo envolvendo "significados culturais, interações sociais e a própria subjetividade" (Simões, 2004:432). É importante dizer que, em formulações discursivas como esta, é possível haver uma considerável margem para a criação/invenção, o que poderíamos traduzir em termos de agência (Giddens, 2009).

Tomando a questão sexual como mote, obviamente em virtude das questões que com mais afinco persegui ao longo da pesquisa, Jonas percorria diversos recônditos de sua geografia pessoal, como a infância, a relação com os familiares, sua trajetória sexual e afetiva, a construção de si, seus projetos e desejos etc., porém de maneira ambivalente ou, se preferirmos outro termo, complexa. No terreno das emoções, por exemplo, Jonas evocava tanto sentimentos positivos ("o bom [de ser gay] é porque eu posso 'fechar', brincar, ser eu mesmo, mostrar meu lado afetivo. Isso é o lado bom") quanto negativos, estando estes associados à tristeza e ao sofrimento produzidos pela discriminação ("o ruim só são as críticas, a violência física, os olhares, a dificuldade de emprego...") ou mesmo pela "desilusão" no campo afetivo. Também no que se referia ao gênero, como registrado anteriormente, a ambivalência se fazia presente: "eu me vejo um pouco assim, masculino, no modo de me portar em certos locais, conversar com alguém"/"tem momentos em que eu me vejo como mulher. Me vejo, penso como mulher, ajo às vezes como mulher"). $\mathrm{O}$ pêndulo reflexivo também era acionado, conferindo um valor ora positivo, ora negativo, quando em pauta estavam questões relacionadas a ou tangenciando aspectos como religião, condição socioeconômica, geração e identidade étnico-racial.

Atribuindo pesos variáveis, portanto, a cada um desses marcadores, Jonas construía uma narrativa que, a depender do momento e das circunstâncias de sua formulação, de seus interesses, do cenário interacional e de seu(s) interlocutor(es), poderia ser lida como uma história de heroísmo ou vitimização, como uma queixa, um lamento ou mesmo um manifesto. De uma maneira ou de outra, penso que as considerações de Henrietta Moore (2000) a respeito do sujeito e de seus múltiplos pertencimentos são percucientes para refletirmos a respeito de situações como esta, tão bem ilustrada por Jonas. Para a autora, a história pessoal de um indivíduo é também a história de uma infinidade de intersecções entre discursos, situações, identidades coletivas, o que confere feições bastante complexas e até imprevisíveis às equações que abarcam "estrutura e práxis", "o social e o indivíduo" (Moore, 2000:15). Este último, assevera a autora, porque pode assumir diversas "posições de sujeito", de acordo com "diferentes discursos", se constitui como um ser do conflituoso e contraditório (Moore, 2000:22, 28), o que tem a ver com, entre outras coisas, a noção de "investimento", tal como formulada por Wendy Holloway. Tal noção englobaria fatores de ordem emocional, mas também racional, isto por incluir em seu horizonte a obtenção de "benefícios materiais, sociais e econômicos". Além da ideia de investimento, uma outra, a de fantasia, desempenha um papel igualmente fundamental, pois se refere ao tipo de pessoa que se gostaria de

discriminatórios, o mesmo não se dando no caso de mulheres lésbicas. Em linhas gerais, o fato de "saírem do armário", de agenciarem suas sexualidades e performances de gênero de forma explícita "justificaria" ou explicaria a violência por ele/as sofrida. 
ser e ao tipo de pessoa que se gostaria que os outros acreditassem que se é" (Moore, 2000:36), ou seja, a algo nomeável como "reputação"15, cujo comprometimento "poderia significar uma perda de condições de sobrevivência" do indivíduo e a impossibilidade "de seguir várias estratégias ou cursos de ação" (Moore, 2000:36).

Se é verdade que somos "sempre diferentes" e que estamos sempre "negociando diferentes tipos de diferenças", como escreveu Stuart Hall (2003:346), devemos estar atentos para a necessidade de percebermos que aquilo que o sujeito demanda/reivindica para si não coincide necessariamente com o que os outros estão dispostos a lhe conceder/atribuir. Ou seja, existe uma distinção fundamental entre aquilo que Brah (2006:362) chama de "inscrição" e "atribuição". Atentando para a diversidade de histórias que podem coabitar um mesmo contexto, a autora aponta para a possibilidade de a diferença servir "como meio de afirmar a diversidade", mas também para os riscos de ela ser "instrumentalizada", sustentando assim "práticas excludentes e discriminatórias" (Brah, 2006:365). Está em jogo aqui também a questão identitária (sempre ela!), jogo este que se dá a partir e através da imbricação da experiência e da subjetividade do indivíduo, das relações sociais, ou, em outros termos, "de circunstâncias pessoais, sociais e históricas" (Brah, 2006:371), numa relação sempre complexa e no mais das vezes contraditória, de maneira tal que a diferença pode tanto desembocar em "desigualdade, exploração e opressão", como em "igualitarismo, diversidade e formas democráticas de agência política" (Brah, 2006:371, 374).

Essa perspectiva teórica é oportuna, pois, sem negar a dimensão ética da identidade, permite a apreensão de uma outra dimensão, bem menos positiva, que diz respeito aos múltiplos processos de sujeição a que os indivíduos podem estar expostos, sobretudo no caso de indivíduos em situação de vulnerabilidade social, como os multiplamente estigmatizados. A propósito, mesmo concordando com Laura Moutinho (2004:361), quando esta, refletindo sobre a discriminação contra negros e homossexuais, afirma não se tratar de uma mera "soma de 'prejuízos' ou apenas um acúmulo de sujeições combinadas", não pude deixar de notar, na situação trazida por Jonas, uma combinação nada vantajosa para ele dos elementos sexualidade/performance de gênero/crença/classe e raça. Contudo, é importante dizer que tal percepção somente me foi possível graças à apreensão de discursos/comentários emitidos por outros atores sociais, alguns integrantes do Grupo Fórum LGBT, mas também de pessoas de Catolé do Rocha, com quem Jonas mantinha algum tipo de relação. Tais discursos/comentários, como já foi dito, em algumas de suas versões censuravam o comportamento de meu interlocutor, ora fazendo ressalvas à sua performance de gênero, ora à sua crença ou adesão religiosa, o que resvalava em seu componente racial. Assim, para muitos desses atores Jonas não tinha emprego (e dificilmente viria a tê-lo) por não saber "comportar-se", havendo aqui, portanto, uma atribuição de responsabilidade ou culpa ao sujeito sujeitado.

\section{Uma reflexão final a partir de uma realidade distópica}

Via-crúcis: via dolorosa; grave provação, conjunto de terríveis experiências; martírio, tormento. Penso na cena de suplício narrada com crueza e vivacidade por Foucault em "O corpo dos condenados", capítulo que abre o seu Vigiar e punir (1987). Penso em Jonas e no Brasil dos dias atuais, no Brasil dos "nossos" dias. Afinal, foi a constatação desse processo disciplinador imposto a Jonas em sua vida cotidiana que me inspirou a escrever o presente texto. Acompanhar um indivíduo ser atravessado sistematicamente por tal processo me conduziu a uma reflexão a respeito das diversas modalidades de suplício a que sujeitos como Jonas estão expostos na sociedade brasileira atual. A problemática evocada aqui, portanto, não se limita à história de um único indivíduo apenas. Na verdade, estamos diante de uma questão macrossocial, que apresenta diferentes matizes e adentra os mais variados âmbitos da vida social. Ora, o "caso Jonas" ilustra, entre outras coisas, a velha tensão e as fraturas presentes no âmago do movimento LGBT nacional,

\footnotetext{
${ }^{15}$ Algumas passagens do discurso proferido por Jonas são reveladoras da preocupação por ele manifestada quanto à sua reputação: "Eu não tenho essa prática de estar gritando no meio da rua, de estar fazendo certos vulgarismos que alguns gays machos têm o costume [de fazer]. Aí, para não perder a amizade, eu tento me portar à altura"/"Eu sei me envolver com todos os grupos. Mesmo às vezes não gostando de estar muito envolvido com os que dizem ou que são de classe alta. Mas eu sei me envolver com todos".
} 
donde a própria sigla, a despeito de seu ideal agregador, demonstra, quando escrutada qualitativamente, uma série de disputas e ausências, de censuras e discriminação, muitas vezes originadas na dificuldade de se lidar com a diferença (diferença de classe, raça, sexualidade, crença, gênero, geração, etc.). Ou seja, ilustra o fato de que, por trás de um discurso inclusivo, ocorre na prática uma série de exclusões (cf. Facchini, 2005; MacRae, 2018).

Além disso, este caso nos convida a uma análise das políticas públicas nos níveis local, estadual e nacional, sem a qual não poderemos entender fatos como o do próprio surgimento do Grupo Fórum LGBT Catolé. Os anos 2000, a partir do governo de Luís Inácio Lula da Silva, marcam um período histórico importante para o movimento $e$ as políticas voltadas para a população LGBT no Brasil. Na Paraíba, durante a gestão de Ricardo Coutinho (do PSB), eleito governador do estado em 2011 e reeleito em 2015, a política do Governo Federal teve continuidade a níveis estadual e municipal, de modo que a criação de ONGs LGBT no Estado deve ser vista como consequência dessa política. Ocorre que, concomitantemente a este fenômeno, assistimos ao surgimento e expansão de uma frente político-religiosa que viu seu poder crescer exponencialmente nos últimos anos, o que passou a afetar enormemente políticas progressistas voltadas para este segmento populacional, promovendo assim o que Marcelo Natividade e Leandro de Oliveira (2013) apropriadamente chamaram de "novas guerras sexuais". Na impossibilidade de estender-me acerca desse tópico, devo dizer que encontrei um Grupo Fórum LGBT agonizando. A ONG não tinha uma sede própria ${ }^{16}$ e, durante minha permanência em Catolé do Rocha, o Grupo estava praticamente paralisado. Conversando com seus integrantes, fiquei sabendo que a prefeitura do município em nada auxiliava este coletivo, muito pelo contrário, sendo um dos motivos o fato de a primeira-dama do município ser evangélica. Este fenômeno, relativo à imiscuição entre política e religião, comprometeu profundamente a continuidade das atividades do Grupo Fórum. Ou seja, nenhuma atividade do Grupo tinha o apoio da prefeitura do município. As garotas transexuais, que antes puderam contar com uma van da prefeitura, que as levava até João Pessoa para serem acompanhadas no tratamento de hormonização (em um dos primeiros ambulatórios criados no país para atender travestis e transexuais), depois de algum tempo tiveram de se acostumar com um sonoro "Não" e a justificativa de que a van só estaria disponível em casos de doença.

Nasci na alvorada dos anos 1980, período em que a vida brasileira estava ainda sob o jugo de um governo militar. Porque aqueles não foram os anos mais duros, foi nos livros, filmes $e$ documentários que aprendi sobre regimes autoritários, de modo que por muito tempo acreditei que personagens como Hitler, Mussolini, Franco, Médici pertenciam a um passado irrecuperável de nossa história. Quanto à questão LGBT, igualmente cheguei a crer que estávamos inseridos num movimento de inexorável libertação. Ledo engano. Durante os meus anos como aluno de graduação, a palavra fascismo, quando pronunciada, invariavelmente gerava controvérsia, pois, para muitos, tal vocábulo não fazia mais nenhum sentido no século XXI. Todavia, talvez em função dos acontecimentos que sobrevieram, marcando profundamente a política $e$ a sociedade brasileira nesta segunda década do século, refletir acerca do fascismo tornou-se irresistível para mim. Lembrome particularmente (mais pelo título do que propriamente por seu conteúdo) de um artigo de Edward Luttwak, "Por que o fascismo é a onda do futuro?" (1994), que li ainda na idade da inocência, e me pergunto: seria o fascismo a onda do futuro? a onda do presente? Em um texto de João Fábio Bertonha (1995), que é um comentário a respeito do artigo de Luttwak, o autor, analisando o fascismo (à maneira de Wilhelm Reich, 1988) em seus aspectos psicológicos/psicanalíticos e sociais/políticos, nos diz haver

certos fatos dentro do fascismo que só são compreensíveis se assumirmos que ele tem o poder de manipular algumas das energias mais íntimas do ser humano, como a agressividade e a afetividade, canalizando essas energias para seus fins (Bertonha, 1995:116).

\footnotetext{
${ }^{16} \mathrm{Em} 2015$, um ano após eu ter dado início à minha pesquisa, o fundador do Grupo Fórum alugou uma sala de um sobrado localizado no Centro de Catolé do Rocha, para ser a sede da ONG. Investindo recursos próprios e esperando poder contar com a colaboração de pessoas da cidade, a expectativa era de que o Grupo Fórum conseguisse manter uma agenda regular de reuniões e outras atividades. Contudo, sem o efetivo apoio esperado, e diante das dificuldades financeiras para manter o local, poucos meses depois a sede desapareceu e seu idealizador decidiu afastar-se do Grupo.
} 
Nas palavras de Bertonha, o fascismo tem uma "habilidade fantástica" de lidar com o inconsciente humano $e$ "de usá-lo para adquirir popularidade de massa (Ibidem) ${ }^{17}$. A propósito ainda do fascismo, Fernando Horta (2017:1) aponta três fatores que tornam sua emergência possível: i) "negação da política como ferramenta de solução dos conflitos sociais"; ii) "desprezo pelo que é diferente cultural, política ou socialmente"; e iii) "fortalecimento do ideal punitivista jurídico ou físico". A conjunção destes fatores tem como corolário a violência. Daí a disseminação de pânicos morais, de fascismos moleculares, de intolerância generalizada, reconfigurando uma geografia político-moral marcada pela gradativa redução do campo de possibilidades para os sujeitos pensarem e agirem. A propósito dessas questões, tenho dois comentários mais a fazer. O primeiro nos conduz novamente às considerações de duas autoras já evocadas neste texto. De acordo com Moore (2000:35), para entendermos adequadamente os discursos produzidos sobre o gênero (e poderíamos ir além, incluindo os discursos sobre sexualidade, raça, crença, origem, nacionalidade etc.), é preciso levar em conta "processos mais amplos de mudança econômica e política", já que estes discursos têm a ver com poder e relações políticas nos mais variados níveis. Daí então - e aqui já estamos pensando com Brah (2006:359) - a necessidade de buscarmos entender como são articulados discursos e práticas e como estes se inscrevem nas relações sociais e nos sujeitos, produzindo diferença e/ou desigualdade.

O segundo e último comentário nos leva ao encontro da reflexão de Cardoso de Oliveira (2006) acerca da ética da liberdade ou, se preferirmos, da liberdade do sujeito ético. Para o autor, o "Eu" (Self) somente se plenifica quando exerce sua liberdade, quando conquista autonomia para agir, viver e escolher o "tipo de self que ele deseja ser" (Cardoso de Oliveira, 2006:80). Se é mesmo verdade que "o pessoal é político", como escreveu Carol Hanish, numa atualização feminista da célebre tese aristotélica, é imperativo (como sempre, talvez como nunca antes) combatermos a intolerância e o fascismo disseminado nas micro e macrorrelações sociais, para que assim possamos de fato e de direito exercermos a liberdade, uma liberté libre, como diria Rimbaud: liberdade para ser aquilo que se deseja ser; liberdade para Jonas; liberdade para todos nós.

\section{Referências bibliográficas}

BERTONHA, João Fábio. Seria o inconsciente humano fascista? Um comentário ao texto de Edward Luttwak. Cultura Vozes, São Paulo, v. 89, n.5, 1995, pp.112-128.

BRAH, Avtar. Diferença, diversidade, diferenciação. cadernos pagu (26), Campinas, Núcleo de Estudos de Gênero-Pagu/Unicamp, janeiro-junho de 2006, pp.329-376

BRAH, Avta; PHOENIX, Ann. "Ain't I a Woman?" Revisiting Intersectionality. Journal of International Women's Studies, Bridgewater, v. 5, n. 3, 2004. pp.75-86

BUTLER, Judith. Performative Acts and Gender Constitution: An Essay in Phenomenology and Feminist Theory. In: CASE, Sue-Ellen (org.). Performing Feminisms, Feminist Critical Theory and Theatre. Baltimore, The John Hopkins Press, 1990.

DÍAZ-BENÍTEZ, María Elvira. Negros homossexuais: raça e hierarquia no Brasil e na Colômbia. Dissertação (Mestrado em Antropologia Social), PPGAS/Museu Nacional/UFRJ, Rio de Janeiro, 2005.

ERIBON, Didier. Reflexóes sobre a questão gay. Rio de Janeiro, Companhia de Freud, 2008.

FACCHINI, Regina. Sopa de letrinhas: movimento homossexual e produção de identidades coletivas nos anos 1990. Rio de Janeiro, Garamond, 2005.

FERREIRA, Paulo Rogers. Os afectosmal-ditos: o indizível das sexualidades camponesas. Dissertação (Mestrado em Antropologia Social), PPGAS/Universidade de Brasília, 2006.

\footnotetext{
17 "É difícil entender, de fato, a pulsão pela morte que levou o nazismo a destruir tudo em seu redor e se autodestruir quando de sua derrota militar, a sua fúria anti-semita, a submissão voluntária de milhares de pessoas às figuras de Hitler e Mussolini, o infinito sucesso de sua ritualística e de sua simbologia e outros aspectos sem recorrer à psicologia; sem pensar nos desejos de morte e vida do ser humano, no consolo que é a projeção no outro de todas as perversões em oposição à nossa total pureza, na vontade de sublimar o amor próprio e a individualidade e se submeter a um líder em favor da incorporação a um todo confortante e renovador das energias psíquicas e em outros aspectos que nossa ignorância nos mecanismos psicológicos da mente humana nos impedem de desenvolver a contento" (Bertonha, 1995:117).
} 
FERREIRA, Paulo Rogers. A natureza e o imaginário: dos jogos eróticos em sociedades rurais. Habitus, v. 5, n. 2, Goiânia, jul./dez. 2007, pp.375-394.

FOUCAULT, Michel. Vigiar e punir: nascimento da prisão. Petrópolis, Vozes, 1987.

FOUCAULT, Michel. História da sexualidade I: a vontade de saber. Rio de Janeiro, Edições Graal, 1988.

FRY, Peter. Homossexualidade masculina e cultos afro-brasileiros. In: Para inglês ver: identidade e politica na cultura brasileira. Rio de Janeiro, Jorge Zahar Editor, 1982a, pp.54-86.

FRY, Peter. Da hierarquia à igualdade: a construção histórica da homossexualidade no Brasil. In: Para inglês ver: identidade e politica na cultura brasileira. Rio de Janeiro, Jorge Zahar Editor, 1982b, pp.87-115.

GIDDENS, Anthony. A constituição da sociedade. São Paulo, Martins Fontes, 2009.

GONTIJO, Fabiano de Souza. Diversidade sexual e de gênero no mundo rural brasileiro: esboço de reflexões preliminares. Revista FSA, v. 10, n. 2, Teresina, abr.jun. de 2013, pp.84-100.

GONTIJO, Fabiano de Souza. Outros campos, outros desejos? considerações sobre família, amor, gênero e sexualidade no Piauí. Amazônica 3(2), 2011, pp.268-286.

GONTIJO, Fabiano de Souza; COSTA, Francisca Célia da Silva. "Ser traveco é melhor que mulher": considerações preliminares acerca das discursividades do desenvolvimentismo e da heteronormatividade no mundo rural piauiense. Bagoas, n. 08, Natal, 2012, pp.171-186.

GUIMARÃES, Carmen Dora. O homossexual visto por entendidos. Rio de Janeiro, Garamond, 2004.

HALL, Stuart. Da diáspora: identidades e mediações culturais. Belo Horizonte, UFMG, 2003.

HEILBORN, Maria Luiza. Dois é par: gênero e identidade sexual em contexto igualitário. Rio de Janeiro, Garamond, 2004.

HENNING, Carlos Eduardo. As diferenças na diferença: hierarquia e interseções de geração, classe, raça $e$ corporalidade em bares e boates GLS. Dissertação (Mestrado em Antropologia Social), PPGAS/UFSC, Florianópolis, 2008.

HORTA, Fernando. O fascismo nosso de cada dia... ou quem será comido primeiro?. GGN. https://www.geledes.org.br/o-fascismo-nosso-de-cada-dia-ou-quem-sera-comido-primeiro-por-fernando-horta/ _ acesso em 10/09/2019

LACOMBE, Andrea. Ler(se) nas entrelinhas: sociabilidades e subjetividades entendidas, lésbicas e afins. Tese (Doutorado em Antropologia Social), PPGAS/Museu Nacional/UFRJ, 2010.

LUTTWACK, Edward. Por que o fascismo é a onda do futuro?. Novos Estudos CEBRAP, São Paulo, n 40 , novembro1994, pp.145-151.

MACRAE, Edward. A construção da igualdade: identidade sexual e política no Brasil da "Abertura". Campinas, Editora da UNICAMP, 1990.

MARQUES, Roberto. Homoerotismo no Cariri cearense: inscrições de um objeto em suas relações com o silêncio. MÉTIS: história \& cultura, v. 10, n. 20, jul./dez. 2011, pp.197-217.

MCCLINTOCK, Anne. Couro imperial: raça, gênero e sexualidade no embate colonial. Campinas, SP, Editora da Unicamp, 2010.

MOORE, Henrietta L. Fantasias de poder e fantasias de identidade: gênero, raça e violência. cadernos pagu (14), Campinas, Núcleo de Estudos de Gênero-Pagu/Unicamp, 2000,pp.13-44

MOUTINHO, Laura. Sexualidade, "raça" e direitos na África do Sul: primeiras reflexões. In: PISCITELLI, Adriana; GREGORI, Maria Filomena; CARRARA, Sérgio (org.). Sexualidade e saberes: convenções e fronteiras. Rio de Janeiro, Garamond, 2004,pp.345-363.

NATIVIDADE, Marcelo; OLIVEIRA, Leandro de. As novas guerras sexuais: diferença, poder religioso e identidade LGBT no Brasil. Rio de Janeiro, Garamond, 2013.

OLIVEIRA, Roberto Cardoso de. O Eu, suas identidades e o mundo moral (A liberdade do sujeito ético). In: OLIVEIRA, Roberto Cardoso de.Caminhos da identidade: ensaios sobre etnicidade e multiculturalismo. São Paulo, Editora Unesp; Brasília, Paralelo 15, 2006,pp.59-86. 
PARKER, Richard. Abaixo do equador: culturas do desejo, homossexualidade masculina e comunidade gay no Brasil. Rio de Janeiro, Record, 2002.

PARKER, Richard. A construção da solidariedade: AIDS, sexualidade e política no Brasil. Rio de Janeiro, Relume Dumará, ABIA, IMS, UERJ, 1994.

PARKER, Richard. Corpos, prazeres e paixões: a cultura sexual no Brasil contemporâneo. São Paulo, Best Seller, 1991.

PERLONGHER, Néstor. O negócio do michêe: prostituição viril em São Paulo. São Paulo, Editora Brasiliense, 1987.

PISCITELLI, Adriana. Interseccionalidades, categorias de articulação e experiências de migrantes brasileiras. Sociedade e Cultura, v.11, n.2, jul/dez. 2008, pp.263-274.

REICH, Wilhelm. Psicologia de massas do fascismo. São Paulo, Martins Fontes, 1988.

SIMÕES, Júlio Assis. Homossexualidade masculina e curso da vida: pensando idades e identidades. In: PISCITELLI, Adriana; GREGORI, Maria Filomena; CARRARA, Sérgio (org.). Sexualidade e saberes: convenções e fronteiras. Rio de Janeiro, Garamond, 2004, pp.415-447.

TEIXEIRA, Alexandre Eustáquio. Discursos e representações sobre os territórios de "pegação" em Belo Horizonte. In: DÍAZ-BENÍTEZ, María Elvira; FÍGARI, Carlos Eduardo (org.). Prazeres dissidentes. Rio de Janeiro, Garamond, 2009, pp.263-288.

VALE DE ALMEIDA, Miguel. Senhores de si: uma interpretação antropológica da masculinidade. Lisboa, Fim de século, 1995. 